\title{
СУЧАСНИЙ СТАН СТУДЕНТСЬКОЇ НАУКИ, ЇЇ ПЕРСПЕКТИВИ ТА ПРОБЛЕМИ: ДОСВІД СТУДЕНТСЬКОГО НАУКОВОГО ГУРТКА КАФЕДРИ ОНКОЛОГІї НМУ ІМ. О. О. БОГОМОЛЬЦЯ
}

\author{
P. I. Верещако, О. С. Зотов, О. В. Поступаленко \\ Національний медичний університет імені О. О. Богомольия, м. Київ
}

\section{CURRENT STATE OF STUDENTS' SCIENCE, PERSPECTIVES AND PROBLEMS: EXPERIENCE OF STUDENT SCIENTIFIC SOCIETY OF THE ONCOLOGY DEPARTMENT IN O. O. BOHOMOLETS NATIONAL MEDICAL UNIVERSITY}

\author{
R. I. Vereschako, O. S. Zotov, O. V. Postupalenko \\ National Medical University by O. O. Bohomolets, Kyiv
}

\begin{abstract}
Відмічається високий інтерес серед студентів до науково-дослідницької роботи. Але осторонь від неї залишається значний резерв потенційних перспективних молодих науковців через слабку мотивацію та непевних перспектив кар'єри вченого-дослідника. Кадрова проблема та демотивація молодих спеціалістів - цілком вірогідний наслідок цієї проблеми, при відсутності відповідних заходів щодо її вирішення.
\end{abstract}

\begin{abstract}
Students show high level of interest in scientific and research work. Considerable reserve of potential and promising young scientists remains aside from it. The reason is poor motivation and uncertain perspectives for scientific career.

Staff-problem and demotivation of young specialists are the most likely results of this problem, if there will be no appropriate measures to resolve it.
\end{abstract}

Вступ. Розвиток студентської науки невід’ємно пов’ язаний з діяльністю гуртків при кафедрах, які зазвичай мають наукову спрямованість (т. з. студентських наукових гуртків - СНГ). Проте доповіді гуртківців нерідко можуть зацікавити до відвідування інтернів, магістрів та співробітників кафедри, що підтверджується досвідом СНГ кафедри онкології, на прикладі якого розглянемо сучасні тенденції у розвитку студентської науки.

Гурток, на противагу буденному навчанню, не має таких важелів впливу, як оцінювання, контроль знань (тести, опитування), матеріальне заохочення. Це робить інтерес студента більш щирим, без страху перед покаранням чи зацікавленості у винагороді. Кожен гуртківець має власну мотивацію витрачати свій вільний час та матеріальні ресурси на відвідування гуртка та наукову роботу. Загалом, робота СНГ є саморегульованим процесом, у якому кожен його учасник відіграє важливу роль.

Основна частина. У 1999 р. з метою залучення студентів до наукової роботи, поглибленого вивчення

(ㄱ Р. І. Верещако, О. С. Зотов, О. В. Поступаленко сучасних методик лікування та діагностики онкологічних захворювань був створений СНГ кафедри онкології, який очолив доцент В. С. Чешук (нині професор). Протягом 2002-2005 рр. гурток очолював доцент О. В. Кравченко, з 2006 р. - доцент О. С. Зотов. Більш деталізовану інформацію щодо складу гуртка та його наукової активності представлено в таблиці 1.

Наведені дані (табл. 1) свідчать про підвищення інтересу до онкології серед студентів. Так, у період 3 2008-2013 рр. кількість гуртківців зросла на $218 \%$, кількість друкованих робіт - на $630 \%$, участь у наукових заходах - на $556 \%$. Таким чином збільшилась не лише відвідуваність гуртка, а й наукова активність його членів. Переважна більшість гуртківців - студенти 5-6 курсів, представники медичних факультетів № 1 та № 2 (табл. 2). Відмічається зростаючий інтерес серед студентів, які ще не проходили цикл онкології за навчальною програмою (1-4 курс), але зацікавились неоплазіями під час вивчення інших дисциплін (табл. 3).

Зростання кількості гуртківців відбувається за рахунок представниць жіночої статі, натомість кількість представників чоловічої статі неухильно спадає 
Таблиця 1. Склад гуртка та його наукова активність у 2006-2013 pp.

\begin{tabular}{|c|l|c|c|c|}
\hline $\begin{array}{c}\text { Навчальний } \\
\text { рік }\end{array}$ & \multicolumn{1}{|c|}{ Староста } & $\begin{array}{c}\text { Кількість } \\
\text { гуртківців }\end{array}$ & $\begin{array}{c}\text { Кількість друкованих } \\
\text { робіт гуртківців } \\
\text { (тези/статті) }\end{array}$ & $\begin{array}{c}\text { Участь у наукових заходах* } \\
\text { (в тому числі міжнародних) }\end{array}$ \\
\hline $2006-2007$ & О. Т. Енгел & н/д & н/д & н/д \\
\hline $2007-2008$ & М. А. Волк & н/д & $10(9 / 1)$ & н/д \\
\hline $2008-2009$ & Д. Е. Махмудов & 22 & $20(18 / 2)$ & $21(11)$ \\
\hline $2009-2010$ & Д. Е. Махмудов & 29 & $19(17 / 2)$ & $21(10)$ \\
\hline $2010-2011$ & О. І. Лебедсва & 28 & $34(21 / 13)$ & $31(25)$ \\
\hline $2011-2012$ & О. М. Наумчик & 39 & $63(54 / 9)$ & $50(41)$ \\
\hline $2012-2013$ & О. В. Поступаленко & 48 & & \\
\hline
\end{tabular}

Примітка. *Конференції, конгреси, семінари, освітні програми та школи, елективні курси онкології, майстер-класи, конкурси наукових робіт, наукові форуми і т. п.

Таблиця 2. Розподіл гуртківців за факультетами

\begin{tabular}{|l|c|r|c|c|c|c|c|c|c|}
\hline $\begin{array}{l}\text { Навчаль- } \\
\text { ний рік }\end{array}$ & н/д & $\begin{array}{r}\text { Медич- } \\
\text { ний № 1 }\end{array}$ & $\begin{array}{c}\text { Медич- } \\
\text { ний № 2 }\end{array}$ & $\begin{array}{c}\text { Медич- } \\
\text { ний № 3 }\end{array}$ & $\begin{array}{c}\text { Медич- } \\
\text { ний № 4 }\end{array}$ & ФПЛЗСУ & $\begin{array}{c}\text { Стомато- } \\
\text { логічний }\end{array}$ & $\begin{array}{c}\text { Медико- } \\
\text { психологічний }\end{array}$ & \begin{tabular}{c}
$\Sigma$ \\
\hline $2012 / 2013$
\end{tabular} \\
\hline $2011 / 2012$ & - & $21(44 \%)$ & $16(34 \%)$ & $4(8 \%)$ & $3(6 \%)$ & $1(2 \%)$ & $2(4 \%)$ & $1(2 \%)$ & 48 \\
\hline $2010 / 2011$ & $5(13 \%)$ & $15(31 \%)$ & $20(51 \%)$ & - & $2(5 \%)$ & $5(13 \%)$ & - & - & 39 \\
\hline $2008 / 2009$ & - & $11(65 \%)$ & $5(29 \%)$ & $1(6 \%)$ & - & - & - & - & 39 \\
\hline$\Sigma$ & $5(4 \%)$ & $59(41 \%)$ & $52(36 \%)$ & $9(6 \%)$ & $8(6 \%)$ & $7(5 \%)$ & $2(1 \%)$ & $1(1 \%)$ & 143 \\
\hline
\end{tabular}

Таблиця 3. Розподіл гуртківців за курсами

\begin{tabular}{|l|c|c|c|c|c|c|c|c|}
\hline \multicolumn{1}{|c|}{ Навчальний рік } & н/д & 1 & 2 & 3 & 4 & 5 & 6 & $\Sigma$ \\
\hline $2012 / 2013$ & - & $1(2 \%)$ & $1(2 \%)$ & $13(27 \%)$ & $5(10 \%)$ & $18(38 \%)$ & $10(21 \%)$ & 48 \\
\hline $2011 / 2012$ & - & $2(5 \%)$ & $6(15 \%)$ & $4(10 \%)$ & $8(21 \%)$ & $10(26 \%)$ & $9(23 \%)$ & 39 \\
\hline $2010 / 2011$ & $3(8 \%)$ & $2(5 \%)$ & $2(5 \%)$ & $4(10 \%)$ & $5(13 \%)$ & $10(26 \%)$ & $13(33 \%)$ & 39 \\
\hline $2008 / 2009$ & - & - & - & - & - & $3(18 \%)$ & $14(82 \%)$ & 17 \\
\hline$\Sigma$ & $3(2 \%)$ & $5(3 \%)$ & $9(6 \%)$ & $21(15 \%)$ & $18(13 \%)$ & $41(29 \%)$ & $46(32 \%)$ & 143 \\
\hline
\end{tabular}

(табл. 4). Наразі причини гендерного перекосу залишаються незрозумілими, чи це явище характерне лише для гуртка онкології та пов'язане з його особливостями, чи, можливо, це загальна тенденція до зниження інтересу до наукової роботи серед осіб чоловічої статі.

Засідання гуртка проводиться двічі на місяць, але кожен гуртківець залежно від вподобань та можливостей має індивідуальний графік роботи. Засідання

Таблиця 4. Розподіл гуртківців за статтю

\begin{tabular}{|l|c|c|c|}
\hline Навчальний рік & чол. & жін. & $\Sigma$ \\
\hline $2012 / 2013$ & $8(17 \%)$ & $40(83 \%)$ & 48 \\
\hline $2011 / 2012$ & $13(33 \%)$ & $26(67 \%)$ & 39 \\
\hline $2010 / 2011$ & $14(36 \%)$ & $25(63 \%)$ & 39 \\
\hline $2008 / 2009$ & $5(29 \%)$ & $12(71 \%)$ & 17 \\
\hline$\Sigma$ & $40(28 \%)$ & $103(72 \%)$ & 143 \\
\hline
\end{tabular}

складається з двох частин: теоретичної (усна доповідь на обрану тему або обговорення актуальних питань) та практичної (клінічний обхід хворих у відділеннях Київського міського клінічного онкологічного центру та Національного інституту раку: хірургічного, урологічного, гінекологічного, хіміотерапевтичного, радіологічного, дитячого, торакальної та абдомінальної хірургії, відділення паліативної медицини (хоспісу). Гуртківцям надається можливість ознайомлюватись з історіями хвороби, збирати анамнез, проводити фізикальні обстеження, ознайомлюватись із спеціальними лабораторно-інструментальними методами діагностики злоякісних пухлин та ін. У заздалегідь узгоджені дні членам гуртка надається можливість брати участь у веденні амбулаторного прийому хворих в консультативній поліклініці під керівництвом лікаря онколога-мамолога. Вони також можуть брати участь у клінічних розборах, патологоанатомічних 
розтинах, лабораторних дослідженнях, обходах професора, доцента, а також оперативних втручаннях, перев'язках тощо під час канікул та у вільний від навчання час.

Урізноманітнення формату проведення теоретичної частини засідання (всі доповідачі - студенти) збільшує інтерес гуртківців до відвідування засідань та більш активної участі в них. Науковому керівнику відводиться роль спостерігача та коментатора, який доповнює матеріал літературними даними, власними спостереженнями та думками. Усна доповідь для кращого сприйняття та наочності доповнюється ілюстративним матеріалом презентації. Доповіді базуються на даних літератури або результатах власних досліджень. Практикується проведення тематичних засідань та засідань у форматі круглого столу. Староста гуртка 3 метою об'єднання всіх частин засідання в єдину ідею надає всім учасникам опірні матеріали та контролює підготовку доповідачів. Такий вид роботи дозволяє залучити більше учасників до підготовки засідання, шляхом розкриття загальної теми декількома доповідачами, кожен з яких поглиб- лено висвітлює певний аспект. До дискусії долучається більше учасників, вона проходить значно організованіше. Як результат - обговорення більшого спектра проблем, досягнення консенсусних рішень. Нововведення знайшло широку підтримку серед гуртківців і буде активно розвиватися в подальшому.

Практикуються спільні засідання з гуртками інших кафедр (щелепно-лицевої хірургії, оториноларингології, психології) для міждисциплінарного розгляду тематики засідання. Такий формат проведення засідання об'єднує студентів та наукових керівників гуртків з різноманітними інтересами, які чудово доповнюють один одного на стику своїх дисциплін. Слід відмітити, що в такому випадку виникає значно більше запитань, обговорення проходить набагато активніше. Підвищений інтерес аудиторії підтверджується і тим, що такі засідання відвідують не лише гуртківці кафедр-організаторів, ай студенти, які раніше не відвідували жодного 3 них.

Проаналізувавши тематику засідань за 2008-2013 pp. (табл. 5, табл. 6) та публікацій за 2011-2013 рр. (табл. 7 і табл. 8), можна зробити висновок, що найбільше цікавить студентів в онкології. Це рак молочної зало-

Таблиця 5. Тематика засідань за локалізаціями пухлинного процесу

\begin{tabular}{|c|c|c|c|c|c|c|c|c|c|c|c|c|c|c|}
\hline 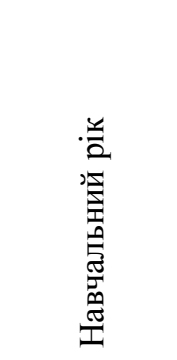 & 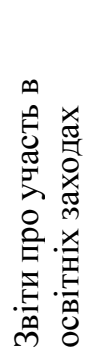 & 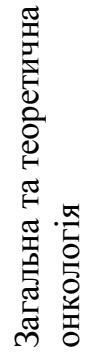 & 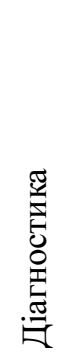 & 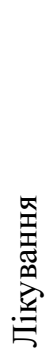 & 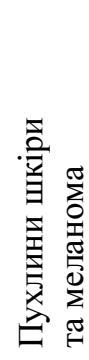 & 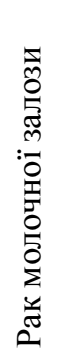 & 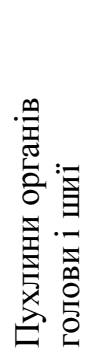 & 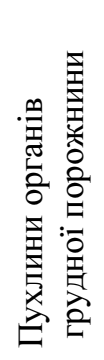 & 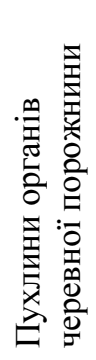 & 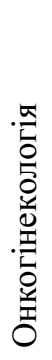 & 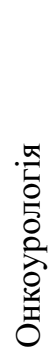 & 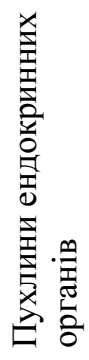 & $\begin{array}{l}. \frac{\pi}{5} \\
0 \\
0 \\
0 \\
0 \\
\overline{0} \\
0 \\
0 \\
0 \\
0 \\
0\end{array}$ & $\omega$ \\
\hline $2012 / 2013$ & 4 & 5 & 5 & 4 & 5 & - & 2 & - & 2 & 2 & - & 3 & 1 & 33 \\
\hline $2011 / 2012$ & 3 & 4 & $\begin{array}{lll}- & & \end{array}$ & 2 & 1 & 10 & - & 1 & 5 & 3 & $\begin{array}{llll}- & \\
\end{array}$ & 1 & 2 & 32 \\
\hline $2010 / 2011$ & 1 & 4 & 5 & - & - & 6 & - & 1 & 3 & - & 1 & - & - & 21 \\
\hline $2008 / 2009$ & - & 1 & 1 & - & - & 4 & - & - & 2 & - & - & 1 & - & 9 \\
\hline$\Sigma$ & $\begin{array}{l}\widehat{\partial} \\
\underset{\infty}{\infty}\end{array}$ & 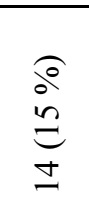 & $\begin{array}{l}0^{\circ} \\
\Xi \\
=\end{array}$ & $\begin{array}{l}\hat{0} \\
\hat{0}\end{array}$ & $\begin{array}{l}i^{\circ} \\
\text { in } \\
i n\end{array}$ & 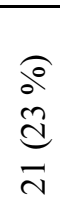 & $\underset{\sim}{\stackrel{d}{d}}$ & 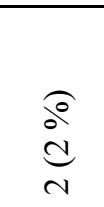 & 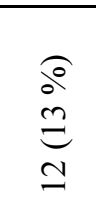 & $\begin{array}{l}00 \\
\text { in } \\
\text { in }\end{array}$ & $\Xi$ & $\begin{array}{l}\text { o } \\
\text { in } \\
\text { in }\end{array}$ & $\begin{array}{l}\stackrel{0}{\circ} \\
\stackrel{n}{n}\end{array}$ & 95 \\
\hline
\end{tabular}

Таблиця 6. Тематика засідань за напрямками онкології

\begin{tabular}{|l|c|c|c|c|c|c|}
\hline $\begin{array}{c}\text { Навчальний } \\
\text { рік }\end{array}$ & $\begin{array}{c}\text { Хірургічне } \\
\text { лікування }\end{array}$ & $\begin{array}{c}\text { Медикаментозна } \\
\text { терапія }\end{array}$ & $\begin{array}{c}\text { Променева } \\
\text { терапія }\end{array}$ & Діагностика & $\begin{array}{c}\text { Загальна та } \\
\text { теоретична онкологія }\end{array}$ & $\Sigma$ \\
\hline $2012 / 2013$ & 4 & - & 2 & 2 & 25 & 33 \\
\hline $2011 / 2012$ & 13 & 1 & 2 & - & 16 & 32 \\
\hline $2010 / 2011$ & 4 & 1 & - & 4 & 12 & 21 \\
\hline $2008 / 2009$ & 2 & 2 & - & 1 & 4 & 9 \\
\hline$\Sigma$ & $23(24 \%)$ & $4(4 \%)$ & $4(4 \%)$ & $7(8 \%)$ & $57(60 \%)$ & 95 \\
\hline
\end{tabular}


Таблиця 7. Тематика публікацій за локалізацією пухлинного процесу

\begin{tabular}{|c|c|c|c|c|c|c|c|c|c|c|c|c|c|}
\hline $\begin{array}{l}\text { Навчаль- } \\
\text { ний рік }\end{array}$ & Інше & $\begin{array}{c}\text { Загальна та } \\
\text { теоретична } \\
\text { онкологія }\end{array}$ & \begin{tabular}{|c|} 
Діа- \\
гнос- \\
тика
\end{tabular} & $\begin{array}{l}\text { Ліку- } \\
\text { вання }\end{array}$ & $\begin{array}{c}\text { Пухлини } \\
\text { шкіри та } \\
\text { меланома }\end{array}$ & $\mid \begin{array}{c}\text { Рак } \\
\text { молочної } \\
\text { залози }\end{array}$ & \begin{tabular}{|c|} 
Пухлини \\
органів \\
голови \\
i шиї \\
\end{tabular} & \begin{tabular}{|c} 
Пухлини \\
органів \\
грудної \\
порожнини
\end{tabular} & $\begin{array}{c}\text { Пухлини } \\
\text { органів } \\
\text { черевної } \\
\text { порожнини }\end{array}$ & $\begin{array}{c}\text { Онко- } \\
\text { гінеко- } \\
\text { логія }\end{array}$ & $\begin{array}{c}\text { Онко- } \\
\text { уро- } \\
\text { логія }\end{array}$ & $\begin{array}{c}\text { Онко- } \\
\text { гемато- } \\
\text { логія }\end{array}$ & $\Sigma$ \\
\hline $\begin{array}{l}2012 / \\
2013 \\
\end{array}$ & $\begin{array}{c}28 \\
(44 \%) \\
\end{array}$ & $\begin{array}{c}4 \\
(6 \%) \\
\end{array}$ & - & $\begin{array}{c}4 \\
(6 \%) \\
\end{array}$ & $2(3 \%)$ & $\begin{array}{c}11 \\
(18 \%) \\
\end{array}$ & $4(6 \%)$ & $1(2 \%)$ & $5(9 \%)$ & $\begin{array}{c}4 \\
(6 \%) \\
\end{array}$ & - & - & 63 \\
\hline $\begin{array}{l}2011 / \\
2012\end{array}$ & $\begin{array}{c}1 \\
(6 \%)\end{array}$ & $\begin{array}{c}4 \\
(13 \%)\end{array}$ & $\begin{array}{c}1 \\
(6 \%)\end{array}$ & $\begin{array}{c}6 \\
(19 \%)\end{array}$ & $2(6 \%)$ & $\begin{array}{c}7 \\
(23 \%)\end{array}$ & - & $2(6 \%)$ & $4(13 \%)$ & $\begin{array}{c}2 \\
(6 \%)\end{array}$ & $\begin{array}{c}1 \\
(6 \%)\end{array}$ & $\begin{array}{c}2 \\
(6 \%)\end{array}$ & 32 \\
\hline$\Sigma$ & $\left|\begin{array}{c}29 \\
(31 \%)\end{array}\right|$ & $8(8 \%)$ & $\begin{array}{c}1 \\
(1\end{array}$ & $\left|\begin{array}{c}10 \\
(11 \%)\end{array}\right|$ & $4(4 \%)$ & $\begin{array}{c}18 \\
(19 \%)\end{array}$ & $4(4 \%)$ & $3(3 \%)$ & $9(10 \%)$ & $\begin{array}{c}6 \\
(6 \%)\end{array}$ & $\begin{array}{c}1 \\
(1 \%)\end{array}$ & $\begin{array}{c}2 \\
(2 \%)\end{array}$ & 95 \\
\hline
\end{tabular}

Таблиця 8. Тематика публікацій за напрямками онкології

\begin{tabular}{|l|c|c|c|c|c|c|c|}
\hline $\begin{array}{c}\text { Навчальний } \\
\text { рік }\end{array}$ & $\begin{array}{c}\text { Хірургічне } \\
\text { лікування }\end{array}$ & $\begin{array}{c}\text { Медика- } \\
\text { ментозна } \\
\text { терапія }\end{array}$ & $\begin{array}{c}\text { Променева } \\
\text { терапія }\end{array}$ & Діагностика & $\begin{array}{c}\text { Загальна та } \\
\text { теоретична } \\
\text { онкологія }\end{array}$ & Інше \\
\hline $2012 / 2013$ & $14(22 \%)$ & $2(3 \%)$ & - & - & $19(30 \%)$ & $28(45 \%)$ & 63 \\
\hline $2011 / 2012$ & $1(3 \%)$ & $5(16 \%)$ & $4(12 \%)$ & $4(12 \%)$ & $17(54 \%)$ & $1(3 \%)$ & 32 \\
\hline$\Sigma$ & $15(16 \%)$ & $7(7 \%)$ & $4(4 \%)$ & $4(4 \%)$ & $36(38 \%)$ & $29(31 \%)$ & 95 \\
\hline
\end{tabular}

зи, загальна та теоретична онкологія, пухлини органів черевної порожнини та можливості використання різноманітних методів діагностики та хірургічного лікування в онкології. Слід відмітити зростання частки гуртківців, які публікують свої роботи, з 38 до 48 \% протягом 2011-2013 рр.

Зростає загальний інтерес до участі у наукових заходах (табл. 9). Значною мірою це пов'язано з тим, що у 2012/2013 н. р. кожне засідання гуртка розпочиналось $з$ анонсу старостою наукових подій в Україні та за їі межами. Після їх відвідування гуртківці охоче діляться досвідом та останніми новинами на засіданнях СНГ. Мотивація йде як від самих гуртківців, так і від наукового керівника. Його роль неможливо недооцінити. Саме він у переважній більшості випадків займається науковою роботою з гуртківцями, дає поради та допомагає проводити дослідження, оформлювати їх результати в тезах чи статтях, допомагає у вирішенні організаційних питань та проведенні конференцій.

Про високий рівень організації науково-дослідницької роботи зі студентами свідчить і той факт, щогуртківці беруть активну участь у I-II турах Bсеукраїнського конкурсу студентських наукових робіт з природничих, технічних і гуманітарних наук, демонструючи високий рівень підготовки.

Традиційно силами та засобами СНГ та Студентського наукового товариства імені О. А. Киселя (CHT) проводиться ряд заходів у рамках Всесвітнього дня боротьби із раком (World Cancer Day). Це театралізовані вистави для пацієнтів дитячого відділення Київського міського клінічного онкологічного цент-

Таблиця 9. Публікації та участь у наукових подіях

\begin{tabular}{|c|c|c|c|c|c|}
\hline \multicolumn{3}{|c|}{ Показники } & $\begin{array}{l}2010 / \\
2011\end{array}$ & $\begin{array}{l}2011 / \\
2012\end{array}$ & $\begin{array}{l}2012 / \\
2013\end{array}$ \\
\hline \multicolumn{3}{|l|}{ Кількість гуртківців } & 39 & 39 & 48 \\
\hline \multirow[t]{4}{*}{$\begin{array}{l}\text { Кількість публікацій за } \\
\text { участю гуртківців }\end{array}$} & \multirow[t]{2}{*}{ загальна } & $\begin{array}{l}\text { журнали та збірники наукових праць } \\
\text { НМУ }\end{array}$ & 23 & 26 & 52 \\
\hline & & інші наукові видання & 8 & 8 & 11 \\
\hline & \multicolumn{2}{|l|}{ статті } & 4 & 13 & 10 \\
\hline & \multicolumn{2}{|l|}{ тези } & 27 & 21 & 53 \\
\hline \multirow{4}{*}{$\begin{array}{l}\text { Участь у конференціях, } \\
\text { з'їздах тощо }\end{array}$} & \multirow[t]{2}{*}{ загальна } & проводилися НМУ & 22 & 24 & 29 \\
\hline & & проводилися іншими установами & 5 & 7 & 21 \\
\hline & \multicolumn{2}{|c|}{ міжнародні } & 20 & 25 & 38 \\
\hline & \multicolumn{2}{|c|}{$\begin{array}{l}\text { кількість гуртківців, що взяли участь у щорічній } \\
\text { студентській конференції }\end{array}$} & 12 & 12 & 23 \\
\hline
\end{tabular}


ру. Таким чином студенти намагаються хоч на короткий час відволікти юних пацієнтів та їх батьків від хвороби, яка докорінно змінює їх життя, подарувати свято та надихнути на подальшу боротьбу 3 недугою. Але основною подією є Міжнародний науково-практичний семінар студентів та молодих вчених, присвячений Всесвітньому дню боротьби із раком. Учасники семінару мають можливість не лише надрукувати тези і статті, але й самостійно представити свої наукові роботи (усні та стендові доповіді). Приємно відмітити зростаючий інтерес молоді до даного заходу та високий рівень представлених робіт. Окрім цього, учасники семінару ознайомлюються 3 досвідом втілення у життя високих стандартів надання медичної допомоги онкологічним хворим. Це демонструється на прикладі структури та принципів організації роботи Національного інституту раку і Київського міського клінічного онкологічного центру. Дозвілля іногородніх та іноземних представників протягом всього часу їх перебування в м. Києві організується членами організаційного комітету (за потребою). Традиційно в день пленарних засідань після офіційних заходів всі бажаючі учасники мають можливість у товариській невимушеній атмосфері поспілкуватись один з одним та відвідати Національну оперу України ім. Т. Г. Шевченка. Проведення семінару, присвяченого World Cancer Day, слугує підгрунтям для обміну досвідом та науковими доробками, налагодження та укріплення міжвузівських зв' язків, у тому числі і закордонних. Сподіваємось на подальшу підтримку цього заходу як серед студентів та молодих науковців, так і серед досвідчених керівників та онкологічної спільноти не лише України, а й інших країн.

Серед гуртківців кафедри онкології є інша добра традиція - підвищувати рівень своїх знань протягом літніх канікул, відвідуючи профільні навчальні програми (табл. 10) "Elective Course in Oncology for Medical Students" (організатор - European Cancer Organization (ECCO)), "Basic Oncology Course for young doctors \& students" (організатор - Eurasian Federation of Oncology (EAFO)), "Course on Oncology for Medical Students" (організатор - European School of Oncology (ESO), European Society for Medical Oncology (ESMO)). Відвідуючи їх, гуртківці мають можливість прослухати лекції провідних європейських вчених та ознайомитись 3 новітніми тенденціями у розвитку онкологічної науки, проводити розбір клінічних випадків, ознайомитись із системою надання медичної допомоги онкологічним хворим за кордоном (як теоретично, так і практично, відвідуючи найрізноманітніші підрозділи профільних установ). Окрім цього, учасники отримують безцінний досвід та багато позитивних емоцій як від навчальної програми, так і від спілкування з представниками інших країн. Це слугує добрим підгрунтям для вдосконалення рівня англійської мови та розширення кругозору, ознайомлення з системою медичної освіти різних країн.

Виходячи з вищенаведеного, спостерігається високий інтерес студентів в галузі онкології. Зрозуміло, що, відвідуючи СНГ, частина гуртківців бажає продовжити свою медичну освіту в галузі онкології, інші ж просто розширюють свій кругозір та проявляють інтерес до тематики роботи гуртка, хоча і не бажають працювати онкологами. Ситуація зі студентською наукою та післядипломною освітою має ряд невирішених питань, які з кожним роком ускладнюють шлях становлення молодого спеціаліста та науковця (табл. 11).

Наприклад, відсутність виписки з трудової книжки з записом про прийом на роботу в базовий заклад (установу) охорони здоров'я на посаду лікаря-інтерна, яку формально вимагають при вступі згідно з наказом MO3 № 157 від 09.07.1993 р. “Про впровадження підготовки магістрів медицини у медичних вищих навчальних закладах" (із змінами, внесеними згідно з наказом МО3 № 295 від 24.09.96), унеможливлює вступ випускника контрактної форми навчання до магістратури. Таке ставлення до цієї категорії випускників, з юридичної точки зору, порушує рівність прав на післядипломну освіту, які гарантують Конституція України (ст. 53) та Закон України “Про освіту". Звичайно, що є нагальна потреба приведення таких підзаконних актів, як наказ №291 від 19.09.1996 p. "Про затвердження Положення про спеціалізацію (інтернатуру) випускників вищих медичних і фармацевтичних закладів освіти III-IV рівня акредитації медичних факультетів університетів" (із змінами, внесенимизгідно з наказом МОЗ№47 від 07.02.2001р.), наказ МО3 № 157 від 09.07.1993 р. “Про впровадження підготовки магістрів медицини у медичних вищих навчальних закладах" (із змінами, внесеними згідно з наказом МО3 № 295 від 24.09.96), наказ МО3 № 12 від 29.01.1998 p. "Про затвердження Положення про клінічну ординатуру”, Постанова МОЗ № 309 від 01.03.1999 р. “Про затвердження Положення про підготовку науково-педагогічних і наукових кадрів" у відповідність до законів Українита державноїполітики.

Випускники, які навчались за державним замовленням, теоретично, знаходяться у більш вигідному становищі щодо перспектив наукової роботи у магістратурі, у якості пошукачів наукових інститутів держави. Проте існуюча система розподілу випускників 
Таблиця 10. Міжнародні освітні курси для студентів та молодих лікарів, у яких брали участь гуртківці

\begin{tabular}{|c|c|c|c|c|}
\hline Рік & Організатор & Країна & ПІБ студента & Досягнення \\
\hline 2008 & $\begin{array}{l}\text { ESO.ru (ESMO for medical } \\
\text { students) }\end{array}$ & $\begin{array}{l}\text { Мінськ, Республіка } \\
\text { Білорусь }\end{array}$ & Енгел О. Т. & 1 місце \\
\hline \multirow[t]{2}{*}{2009} & \multirow{2}{*}{$\begin{array}{l}\text { ESO.ru (ESMO for medical } \\
\text { students) }\end{array}$} & \multirow{2}{*}{$\begin{array}{l}\text { Мінськ, Республіка } \\
\text { Білорусь }\end{array}$} & Зайвелєва Ю. І. & \\
\hline & & & Лиходей К. О. & \\
\hline \multirow[t]{2}{*}{2010} & \multirow{2}{*}{$\begin{array}{l}\text { ESO.ru (ESMO for medical } \\
\text { students) }\end{array}$} & \multirow[t]{2}{*}{ Іоаніна, Греція } & Войтко В. О. & \\
\hline & & & Махмудов Д. Е. & \\
\hline \multirow[t]{4}{*}{2011} & \multirow[t]{2}{*}{ ESO (ESMO for medical students) } & \multirow[t]{2}{*}{ Іоаніна, Греція } & Рекута А. С. & \\
\hline & & & Слав'янська К. В. & \\
\hline & \multirow{2}{*}{$\begin{array}{l}\text { EAFO (Basic Oncology Course } \\
\text { for young doctors \& students) }\end{array}$} & \multirow{2}{*}{$\begin{array}{l}\text { Суздаль, Російська } \\
\text { Федерація }\end{array}$} & Лебедєва О. І. & 1 місце \\
\hline & & & Чехун С. В. & \\
\hline \multirow[t]{6}{*}{2012} & ESO (ESMO for medical students) & Іоаніна, Греція & Жежерун М. О. & \\
\hline & \multirow{5}{*}{$\begin{array}{l}\text { ECCO (Elective Course in } \\
\text { Oncology for Medical Students) }\end{array}$} & \multirow[t]{4}{*}{ Антверпен, Бельгія } & Бєлова О. Г. & \\
\hline & & & Кобилінський О. О. & \\
\hline & & & Поступаленко О. В. & \\
\hline & & & Слав'янська К. В. & \\
\hline & & Познань, Польща & Рекута А. С. & \\
\hline \multirow[t]{4}{*}{2013} & \multirow[t]{2}{*}{ ESO (ESMO for medical students) } & \multirow[t]{2}{*}{ Іоаніна, Греція } & Кобилінський О. О. & \\
\hline & & & Поступаленко О. В. & \\
\hline & \multirow{2}{*}{$\begin{array}{l}\text { ECCO (Elective Course in } \\
\text { Oncology for Medical Students) }\end{array}$} & Антверпен, Бельгія & Скрипець Т. В. & \\
\hline & & Познань, Польща & Ямкова К. В. & \\
\hline
\end{tabular}

Таблиця 11. Післядипломна освіта

\begin{tabular}{|c|c|c|c|c|}
\hline & Показники & $\begin{array}{l}2010 / \\
2011\end{array}$ & $\begin{array}{l}2011 / \\
2012\end{array}$ & $\begin{array}{l}2012 / \\
2013\end{array}$ \\
\hline \multicolumn{2}{|l|}{ Кількість гуртківців } & 39 & 39 & 48 \\
\hline \multirow{3}{*}{$\begin{array}{l}\text { Кількість гуртківців, що } \\
\text { продовжили навчання або } \\
\text { роботу на кафедрі }\end{array}$} & магістри & 3 & 0 & 0 \\
\hline & старші лаборанти & 3 & 0 & 0 \\
\hline & інтерни & 3 & 3 & 1 \\
\hline \multicolumn{2}{|c|}{ Кількість гуртківців-випускників, що отримали розподіл за фахом } & 4 & 3 & 0 \\
\hline
\end{tabular}

на робочі місця, насамперед, задовольняє потребу закладів охорони здоров’ я переважно первинної ланки і сільської місцевості у сімейних лікарях та лікарях швидкої допомоги. Клопотання про направлення перспективних молодих науковців у провідні наукові установи та вищі навчальні заклади, зазвичай, не задовольняються.

Прикладом частково успішного вирішення цих проблем є можливість працювати на посаді старшого лаборанта кафедри та проходити інтернатуру в провідних університетських клініках. На жаль, кількість випускників, які можуть розраховувати на подібне працевлаштування, обмежена штатним розкладом кафедр і кількістю ставок старших лаборантів.

Окремо розглянемо роль СНТ у студентській науці та можливі перспективи подальшого розвитку роз- глянемо на основі Положення про студентське наукове товариство імені О. А. Киселя Національного медичного університету імені О. О. Богомольця (наказ по НМУ № 483 від 17.11.2009 р.). Слід відмітити, що гуртківці кафедри онкології беруть активну участь у роботі СНТ (табл. 12). В підтвердження цього на загальних зборах СНТ (17.09.2013 р.) було нагороджено О. В. Поступаленко (старосту СНГ кафедри онкології 2012-2013 н. р.) грамотою за багаторічну роботу, вагомий особистий внесок у розвиток Студентського наукового товариства імені О. А. Киселя та високий професіоналізм.

СНТ є самостійною громадською організацією університету зі студентського самоврядування, що об'єднує на добровільних засадах студентів університету, які виконують науково-дослідну роботу (НДР) 
(п.1.1. Положення). Тому бажаним є спрощення процедури вступу, яка могла б проводитись за наявністю друкованих праць та/або сертифікатів учасника конференцій або, за їх відсутності, рекомендацією наукового керівника.

Таблиця 12. Кількість членів СНТ серед гуртківців

\begin{tabular}{|l|c|c|}
\hline \multicolumn{1}{|c|}{ Навчальний рік } & СНТ & $\Sigma$ \\
\hline $2012 / 2013$ & $19(40 \%)$ & 48 \\
\hline $2011 / 2012$ & $12(31 \%)$ & 39 \\
\hline $2010 / 2011$ & $19(49 \%)$ & 39 \\
\hline $2008 / 2009$ & $5(29 \%)$ & 17 \\
\hline$\Sigma$ & $55(38 \%)$ & 143 \\
\hline
\end{tabular}

Згідно з Положенням, СНТ має забезпечувати органічний зв' язок навчання та НДР (п. 1.3. Положення). Наскільки органічним є цей зв' язок, якщо час та можливість займатися НДР студент має самостійно викроювати, не маючи жодних пільг перед студентами, які не займаються НДР? До речі, можливо значно збільшити потенціал студентської науки шляхом впровадження додаткового часу для заняття НДР у вигляді певної кількості днів на місяць звільнень від занять без потреби у їх відпрацюванні. На сьогодні “органічний зв' язок” реалізується правом учасників конференцій, конгресів, семінарів та інших наукових подій скласти матеріал пропущених занять під час поточного або проміжного контролю знань. Але, на жаль, ця процедура у переважній більшості випадків нічим не відрізняється від відпрацювання пропущеного за будь-яких інших причин заняття. Таким чином, студент витрачає власний час тричі: на виконання НДР, на її представлення у вигляді доповіді на відповідному науковому заході та, як наслідок, на відпрацювання пропущених занять.

У випадку відрядження, окрім вищезазначеного, студент, замість додаткової підготовки, має витрачати час на оформлення документації, збір всіх необхідних підписів в СНТ, на кафедрі та в ректораті. Необхідно отримати згоду 12 представників адміністрації університету (голова СНТ, науковий консультант, завідувач кафедри, декан факультету, начальник планово-фінансового відділу, проректор з економічних питань, проректор з міжнародних зв'язків та науково-педагогічної роботи, проректор з науковопедагогічної, лікувальної роботи та післядипломної освіти, проректор з науково-педагогічної роботи та довузівської підготовки, проректор з наукової роботи, начальник юридичного відділу, головний бухгалтер). Для отримання кожного підпису потрібно пояснити потребу у тому, що саме Ви маєте їхати у відря- дження, і саме Вам університет має відшкодувати кошти за поїздку. Задовольнити прохання можуть, якщо студент навчається за державним замовленням. Спрощення алгоритму візування документів шляхом подання єдиного документа з мінімальною кількістю очних підписів адміністрації університету може значно полегшити ситуацію.

Серед завдань СНТ є формування умов для розкриття наукового і творчого потенціалу студентів, пошук і підтримка талановитих дослідників серед студентів, надання їм усебічної допомоги (п.2.2. Положення). Таким чином, однією з найважливіших умов $€$ виділення додаткового часу для всіх етапів НДР. Дебюрократизація, за якої студент чи молодий науковець буде працювати на благо науки, а не на паперові умовності чи на статистику, матиме сприятливий вплив на формування особистості дослідника, сучасного вченого iз широким демократичним світоглядом.

Заслуговує окремої уваги такий напрям діяльності CHT, як залучення спонсорських коштів та благодійних внесків для підтримки та розвитку науковопрактичної роботи студентів (п.2.3. Положення). В умовах обмеження бюджетних коштів на наукові дослідження, звісно, потерпає і студентська наука. Мінімальний рівень підтримки студентської наукової роботи витратними матеріалами, коштами для участі в наукових конференціях (реєстраційні внески, транспортні витрати, проживання, інші витрати, пов'язані 3 відрядженням) потребує фінансового забезпечення з боку вищого навчального закладу, механізми реалізації якого не опрацьовані. Натомість залучення спонсорів могло б звільнити студентів від реєстраційних витрат, надати додаткові кошти СНТ, допомогти у забезпеченні витратними матеріалами, створити базу для матеріального заохочення активних науковців та підтримки їх розробок.

Голова Ради СНТ має репрезентувати його у стосунках $з$ керівними органами університету та є членом ректорату та Вченої ради університету (п. 3.5.5. Положення). Рада СНТ повинна функціонувати як дорадчо-консультативний орган при ректорі університету та мати змогу виносити питання, які стосуються роботи СНТ, студентської наукової роботи в університеті на розгляд деканатів та вчених рад факультетів, ректорату та Вченої ради університету (пп. 3.4.2, 3.4.8. Положення).

Таким чином, керівництво СНТ має достатньо повноважень для ініціювання розгляду вищенаведених питань керівництвом університету, клопотання до вищих органів влади, зокрема Міністерства охорони здоров’я. Активна позиція наукового консультанта 
СНТ має сприяти подальшому розвитку студентської науки та бути опірною у вирішенні питань як на місцевому, так і на вищих рівнях.

Висновок. Попри всі негаразди, зберігається високий інтерес серед студентів до науково-дослідницької роботи. Значний резерв потенційних перспективних молодих науковців не залучається до неї тому, що мотивації до заняття наукою у сучасного студентства незначні. Складається враження, що обирати свій шлях в науці залишається завзятим альтруїстам, яким не шкода сил, часу, здоров'я та власних коштів заради науки та непевних перспектив кар'єри вченого-дослідника. Якщо така ситуація буде продовжуватись і далі, то ми отримаємо не лише кадрову проблему, але і повну демотивацію молодих спеціалістів.

Студентська наука має відповідати вимогам часу та слугувати надійною опорою для наукового потенціалу держави. Враховуючи значні резерви молодих та перспективних науковців у лавах НМУ ім. О. О. Богомольця, створення більш сприятливих умов для їх розвитку та наукових пошуків може сприяти зростанню інтересу та реалізації молоді у науковій сфері.

Отримано 24.12.14 